\section{Effects of Phosphorus on Morphology and Foliar Nutrient Concentrations of Hydroponically Grown Scaevola aemula $\mathrm{R}$. Br. 'Whirlwind Blue'}

\author{
Stephanie E. Burnett ${ }^{2}$ and Donglin Zhang ${ }^{1}$ \\ Department of Plant, Soil, and Environmental Sciences, University of Maine, \\ 5722 Deering Hall, Orono, ME 04469
}

Lois B. Stack

University of Maine Cooperative Extension, 495 College Avenue, Orono, ME 04473

\author{
Zhongqi He \\ USDA-ARS, New England Plant, Soil, and Water Laboratory, Orono, ME \\ 04469
}

Additional index words. fan flower, greenhouse, hanging basket

\begin{abstract}
In commercial greenhouses, fan flower 'Whirlwind Blue' (Scaevola aemula R. Br.) plants are sensitive to phosphorus applications in the range typically applied to other floricultural crops. To quantify this response, fan flower plants were grown in Hoagland solutions containing $0,20,40,60$, or $80 \mathrm{mg} \cdot \mathrm{L}^{-1} \mathrm{P}$. Plants fertilized with either the highest $\left(80 \mathrm{mg} \cdot \mathrm{L}^{-1}\right)$ or lowest $\left(0 \mathrm{mg} \cdot \mathrm{L}^{-1}\right) \mathrm{P}$ concentrations had significantly shorter stems and smaller shoot dry weights and leaf areas than plants fertilized with 20 to $60 \mathrm{mg} \cdot \mathrm{L}^{-1} P$. Low or high $P$ concentrations negatively impacted flower number; fan flower fertilized with 0 , 60, or $80 \mathrm{mg} \cdot \mathrm{L}^{-1} \mathrm{P}$ had fewer flowering branches and flowers compared with plants fertilized with 20 to $40 \mathrm{mg} \cdot \mathrm{L}^{-1} \mathrm{P}$. Plants receiving no $\mathrm{P}$ had longer roots than those receiving any $P$ and had greater root dry weights than plants receiving all other $P$ concentrations except $20 \mathrm{mg} \cdot \mathrm{L}^{-1}$. Foliar nutrient analysis indicated that although $P$ treatments significantly impacted foliar concentrations of at least some essential macro- and micronutrients, all essential elements were within or near recommended ranges except $P$. Foliar $P$ concentrations exceeded $1 \mathrm{mg} \cdot \mathrm{g}^{-1}$ in fan flower that received even the lowest concentration of supplemental $P$, but leaf chlorosis was only observed in plants grown in 60 to $80 \mathrm{mg} \cdot \mathrm{L}^{-1} P$. As a result of rapid accumulation of $P$ in fan flower foliage and subsequent reductions in flower number and shoot elongation, fan flower should be fertilized with no more than $20 \mathrm{mg} \cdot \mathrm{L}^{-1} \mathrm{P}$.
\end{abstract}

Fan flower is an herbaceous member of Goodeniaceae native to western Australia (Armitage, 1997, 2001). Stems are procumbent and plants have bluish purple or white flowers with petals on only one side of the pedicel that form in leaf axils and at stem tips. Because it flowers prolifically and has interesting flowers and foliage, fan flower is a popular plant for use in hanging baskets or

Received for publication 14 Nov. 2007. Accepted for publication $12 \mathrm{Feb} .2008$.

Maine Agriculture and Forestry Experiment Station Publication \#2996.

We gratefully acknowledge the Maine Agricultural Center for funding this research project; Pleasant View Gardens (Loudon, NH) for donating plant materials; and Youping Sun, Bradley Libby, and Renae Moran for providing advice and assistance. We thank Marc van Iersel and Doug Cox for their helpful comments on an early draft of the manuscript.

${ }^{1}$ Guest professor at Central South University of Forestry and Technology.

${ }^{2}$ To whom reprint requests should be addressed; e-mailsburnett@maine.edu increasingly important to provide growers with specific, accurate recommendations for $\mathrm{P}$ concentrations for all horticultural crops. Overapplication of $\mathrm{P}$ is linked to eutrophication of surface bodies of water. Legislators are becoming increasingly concerned about the effects of greenhouse runoff on water quality (Lea-Cox and Ross, 2001), making it more important to fertilize ornamental greenhouse plants with only the required amount of P. To do this, commercial greenhouse growers need precise fertilizer recommendations for $\mathrm{P}$.

For these reasons, the primary objective of this research was to determine how fan flower morphology is impacted by various $\mathrm{P}$ concentrations under a constant $\mathrm{pH}$. To ensure ease of $\mathrm{pH}$ adjustment, fan flower plants were grown hydroponically, not in typical container substrates. A second objective was to develop $\mathrm{P}$ fertilizer recommendations for fan flower that may be tested in commercial substrates to determine optimal rates for fan flower production. Third, we want to determine how foliar concentrations of essential nutrients are impacted by varying $\mathrm{P}$ concentrations, which may be essential for maintaining plant health.

\section{Materials and Methods}

The substrate was gently rinsed off roots of uniform fan flower cuttings in 84-cell trays obtained from a commercial grower (Pleasant View Gardens, Loudon, NH) on 30 Mar. 2006. Plants were then established in 11.4-L plastic containers (dimensions $=38 \times 25 \times$ $13.5 \mathrm{~cm}^{3}$ ) containing half-strength, modified Hoagland solution without P (Hoagland and Arnon, 1950). Monobasic ammonium phosphate was added to Hoagland solutions at the following concentrations of elemental $\mathrm{P}$ in solution: $0,20,40,60$, or $80 \mathrm{mg} \cdot \mathrm{L}^{-1}$. Ammonium chloride was added to solutions to balance the ammonium concentration in all treatments. Containers were wrapped in aluminum foil to exclude light, and plants (eight per container) were suspended in holes drilled in the container lids and supported by polyester batting. Aquarium pumps supplied ambient air in solutions in each container. Plants were grown in a glass greenhouse. Electrical conductivity and $\mathrm{pH}$ were measured twice weekly. Lime or MES buffer [2-(Nmorpholino)ethanesulfonic acid] was added to adjust $\mathrm{pH}$ as needed to maintain a $\mathrm{pH}$ of 5.5 to 6.5. Hoagland solutions were completely replaced every other week to replenish nutrients. Toward the end of the experiment, water was added to experimental units as needed to maintain solution volumes.

Two or three plants were destructively harvested 21 and $42 \mathrm{~d}$ after transplanting, respectively (21 DAT and $42 \mathrm{DAT}$ ). On those dates, the lengths of the longest stem and root were recorded, and leaf area was measured using a leaf area meter (LI-3000A, 21 DAT; LI-3100C, 42 DAT; LI-COR Biosciences, Lincoln, NE). Roots and shoots (stems and leaves) were dried in a drying room and dry weights were recorded. Fully mature leaves 
were analyzed for mineral nutrient concentrations at a local soil, plant, and water analysis laboratory. All plants harvested from each experimental unit (three plants) were combined to obtain adequate tissue for the analysis. Plants were arranged in a randomized complete block design with three blocks. One container was an experimental unit with eight subsamples (plants) in each experimental unit. Two plants (subsamples) were harvested 21 DAT and three plants (subsamples) were harvested 42 DAT. There were three blocks (experimental units) for each treatment. For all data, excluding the foliar nutrient data, plants were treated as subsamples and the containers were replicates. As a result of small plant size, foliar samples from all subsamples harvested on the final date were combined to obtain adequate tissue for analysis. At 42 DAT, the number of stems containing flowers and the total number of flowers on each plant were recorded. Data were analyzed in SAS (SAS Institute, Inc., Cary, NC) using general linear models and least significant difference means separation.

\section{Results and Discussion}

Morphology. Shoots of fan flower grown in either the highest or lowest P concentrations tended to be smaller than shoots of plants grown in 20 to $60 \mathrm{mg} \cdot \mathrm{L}^{-1} \mathrm{P}$. For example, 42 DAT into hydroponic solutions, branches of fan flower grown in Hoagland solutions with 20 to $60 \mathrm{mg} \cdot \mathrm{L}^{-1} \mathrm{P}$ had similar branch lengths [ 35 to $40 \mathrm{~cm}$ at 42 DAT, respectively (Fig. 1A)]. Conversely, plants grown in solutions containing either the highest $\left(80 \mathrm{mg} \cdot \mathrm{L}^{-1} \mathrm{P}\right)$ or lowest $\left(0 \mathrm{mg} \cdot \mathrm{L}^{-1}\right.$ $\mathrm{P}) \mathrm{P}$ concentrations had significantly shorter branches at 42 DAT. These trends were also reflected in shoot dry weight measurements (Fig. 1B). However, shoot dry weight of plants grown in 40 to $60 \mathrm{mg} \cdot \mathrm{L}^{-1} \mathrm{P}$ were less than those grown in $20 \mathrm{mg} \cdot \mathrm{L}^{-1} \mathrm{P}$. At $21 \mathrm{DAT}$, stem lengths tended to be shorter and shoots had less dry weight when fan flower plants were fertilized with either no $\mathrm{P}$ or the highest $\mathrm{P}$ concentration (Fig. 1A-B). However, this trend was not always significant according to means separation analyses. Fan flower fertilized with either the highest or lowest $\mathrm{P}$ concentrations appeared stunted and did not exhibit much shoot growth during the study. Branches of fan flower grown in the highest $P$ concentration only grew $2.5 \mathrm{~cm}$ between the two measurement dates compared with at least $7.1 \mathrm{~cm}$ or more at other $P$ concentrations $\left[7.1 \mathrm{~cm}\left(0 \mathrm{mg} \cdot \mathrm{L}^{-1} \mathrm{P}\right) ; 20.4 \mathrm{~cm}\left(20 \mathrm{mg} \cdot \mathrm{L}^{-1} \mathrm{P}\right)\right.$; $20.1 \mathrm{~cm}\left(40 \mathrm{mg} \cdot \mathrm{L}^{-1} \mathrm{P}\right) ; 18.2 \mathrm{~cm}\left(60 \mathrm{mg} \cdot \mathrm{L}^{-1}\right.$ $\mathrm{P})$ ]. In addition to reduced stem length and shoot dry weight; P concentrations in Hoagland solutions also affected fan flower leaf area. Plants grown in solutions with 20 $\mathrm{mg} \cdot \mathrm{L}^{-1} \mathrm{P}$ had the largest leaf areas on both 21 and 42 DAT; plants grown with both higher (40 to $80 \mathrm{mg} \cdot \mathrm{L}^{-1} \mathrm{P}$ ) and lower $(0$ $\left.\mathrm{mg} \cdot \mathrm{L}^{-1} \mathrm{P}\right) \mathrm{P}$ concentrations in Hoagland

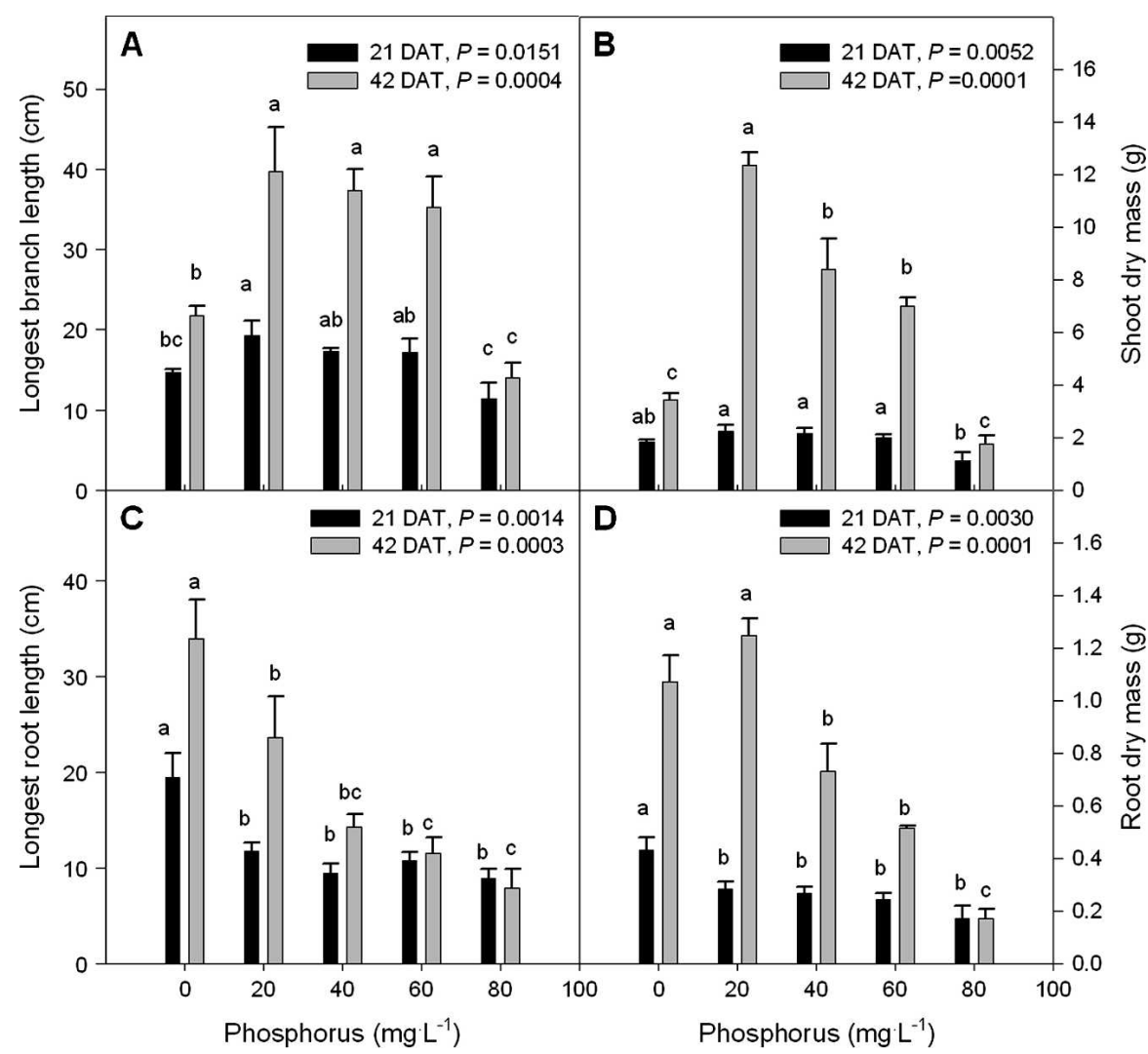

Fig. 1. Effects of phosphorus concentration on longest shoot length (A), shoot dry weight (B), longest root length (C), and root dry weight (D) of hydroponically grown fan flower at 21 and $42 \mathrm{~d}$ after transplanting (DAT). Data represent means of three replications with bars representing SE. solutions had smaller leaf areas at 42 DAT (Fig. 2A).

These results are similar to those reported by Zhang et al. (2004) who noted that either high $\mathrm{P}$ or low substrate $\mathrm{pH}$ reduced stem length and stem number of fan flower 'New Wonder'. It is typical for plants grown without supplemental $\mathrm{P}$ to develop shorter branches. One symptom of $\mathrm{P}$ deficiency is reduced shoot growth (Vance et al., 2003). Lupinus luteus L. (European yellow lupine) plants exhibit shoot dieback and dry matter reduction when applied $\mathrm{P}$ is $32 \mathrm{mg} /$ plant or more (foliar $\mathrm{P}$ concentrations $=1.76 \mathrm{mg} \cdot \mathrm{g}^{-1}$; Warren and Benzian, 1959). Freedan et al. (1989) also reported that Glycine $\max (\mathrm{L}$.) Merr. (soybean) grown in hydroponic solutions with $0.3 \mathrm{mg} \cdot \mathrm{L}^{-1} \mathrm{P}$ had smaller shoot dry weights and less leaf area than soybeans grown with

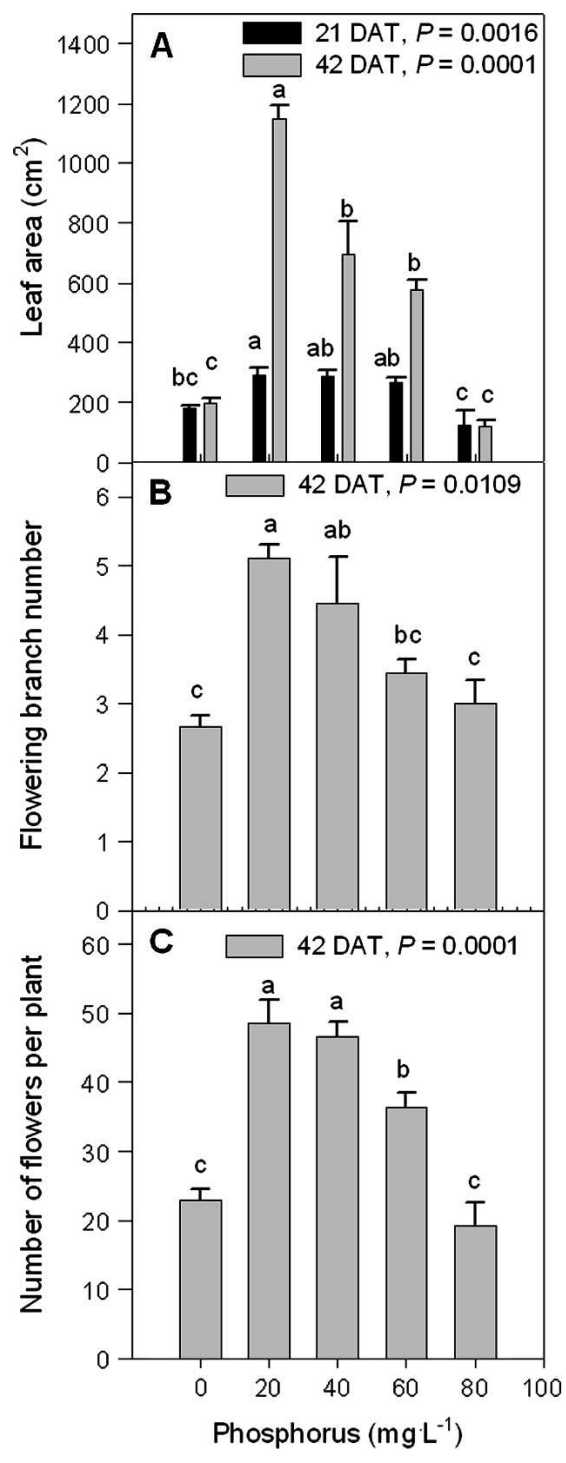

Fig. 2. The effects of $P$ concentration on leaf area (A), number of flowering branches at $42 \mathrm{~d}$ after transplanting (DAT; B), and the total number of flowers present on each plant (C) when fan flower plants were considered marketable (42 DAT). Data represent means of three replications for each treatment with bars representing SES. 
$6.2 \mathrm{mg} \cdot \mathrm{L}^{-1} \mathrm{P}$. Begonia $\times$ semperflorens-cultorum Hort. 'Ambassador Scarlet' (wax begonia) and Petunia $\times$ hybrida Hort. Vilm.-Andr. 'Blue Frost' (petunia) grown on ebb and flow benches without $\mathrm{P}$ fertilizer were shorter and had less dry weight than plants fertilized with 50 to $100 \mathrm{mg} \cdot \mathrm{L}^{-1} \mathrm{P}$ (James and van Iersel, 2001).

When plants were considered marketable (42 DAT), fan flowers grown with $20 \mathrm{mg} \cdot \mathrm{L}^{-1}$ $\mathrm{P}$ in Hoagland solutions had the greatest number of flowering branches and plants with 20 to $40 \mathrm{mg} \cdot \mathrm{L}^{-1} \mathrm{P}$ in solution had greater numbers of flowers than all other treatments (Fig. 2B-C). Like with the data for overall shoot growth, either too much or too little $\mathrm{P}$ reduces fan flower flowering. Because flower number may indicate quality, growers should apply some $\mathrm{P}$, but not more than $20 \mathrm{mg} \cdot \mathrm{L}^{-1} \mathrm{P}$, to avoid negatively impacting flowering and quality.

Root length and dry weight tended to decrease as $\mathrm{P}$ concentrations increased (Fig. $1 \mathrm{C}-\mathrm{D})$. At the termination of the experiment, roots of plants grown in $60 \mathrm{mg} \cdot \mathrm{L}^{-1} \mathrm{P}$ were short but appeared white and healthy. Roots of plants grown in $80 \mathrm{mg} \cdot \mathrm{L}^{-1} \mathrm{P}$ were short and brown. Plants grown in this concentration of $P$ appeared to develop few (if any) new roots after they were transplanted into hydroponics. Existing roots were on average $1 \mathrm{~cm}$ shorter at 42 DAT than at 21 DAT. Unlike shoots, plants grown without $\mathrm{P}$ produced roots that were longer than roots grown at other $\mathrm{P}$ concentrations (Fig. $1 \mathrm{C}$ ) and heavier than roots grown at 40 to $80 \mathrm{mg} \cdot \mathrm{L}^{-1} \mathrm{P}$ (Fig. 1D). Although some researchers have observed reduced root growth in response to $\mathrm{P}$ deficiency (Borch et al., 1999), most researchers agree that $\mathrm{P}$-deficient plants have greater root dry weight than plants grown with sufficient P (Vance et al., 2003). These increases in root dry weight are typically reflected in changes in root architecture as well. Most plants such as Arabidopsis thatiana (L.) Heynh. (mouse ear cress) appear to increase lateral root growth at the expense of a reduction in primary root growth (LópezBucio et al., 2002; Vance et al., 2003).

Foliar nutrient concentrations. Both the highest and lowest $\mathrm{P}$ rates resulted in significant impacts on foliar macro- and micronutrient concentrations (Tables 1 and 2). Foliar concentrations of nitrogen were significantly higher in fan flowers grown in Hoagland solutions with 20 to $60 \mathrm{mg} \cdot \mathrm{L}^{-1} \mathrm{P}$ compared with either 0 or $80 \mathrm{mg} \cdot \mathrm{L}^{-1} \mathrm{P}$ (Table 1). Potassium concentrations were lower in fan flowers grown at the highest $\mathrm{P}$ concentration solution compared with all other treatments (Table 1). Observed root damage when fan flowers were grown in the highest $P$ concentration may have severely limited uptake of all nutrients. In fact, at 42 DAT, even $\mathrm{P}$ foliar concentrations were significantly lower in plants grown in 80 compared with $60 \mathrm{mg} \cdot \mathrm{L}^{-1} \mathrm{P}$ (Table 1 ), possibly as a result of root damage. Plants grown without $P$ had significantly lower magnesium (42 DAT only) and calcium (21 and 42 DAT) concentrations compared with fan flower grown with any supplemental $\mathrm{P}$ (Table 1). Although macronutrient concentrations differed among treatments, foliar macronutrient concentrations of all elements except $P$ were sufficient for plants grown at all $\mathrm{P}$ concentrations (nitrogen sufficiency range $=10$ to $60 \mathrm{mg} \cdot \mathrm{g}^{-1}$; phosphorus sufficiency range $=2$ to $5 \mathrm{mg} \cdot \mathrm{g}^{-1}$; potassium sufficiency range $=15$ to 40 $\mathrm{mg} \cdot \mathrm{g}^{-1}$; magnesium sufficiency range $=1.5$ to $4.0 \mathrm{mg} \cdot \mathrm{g}^{-1}$; calcium sufficiency range $=5$ to $15 \mathrm{mg} \cdot \mathrm{g}^{-1}$; Mills and Jones, 1996).

There were no significant differences in foliar micronutrient concentrations at 21 DAT, but manganese, boron, and zinc foliar concentrations were significantly different at 42 DAT for fan flowers grown in differing $\mathrm{P}$ concentrations in Hoagland solutions (Table 2). Despite the trend for applied P concentrations to impact foliar concentrations of these micronutrients, all were present at near, or above, recommended sufficiency ranges (manganese $=10$ to $50 \mathrm{mg} \cdot \mathrm{g}^{-1}$; boron $=20$ to $100 \mathrm{mg} \cdot \mathrm{g}^{-1}$; zinc $=15$ to $50 \mathrm{mg} \cdot \mathrm{g}^{-1}$; Mills and Jones, 1996). Both the highest and lowest concentrations of $\mathrm{P}\left(0\right.$ and $80 \mathrm{mg} \cdot \mathrm{L}^{-1}$, respectively) resulted in higher levels of some micronutrients than the midlevel $\mathrm{P}$ concentrations. Toxic rates of $\mathrm{P}$ do lead to a reduction in availability of some micronutrients such as zinc, iron, and copper (Marschner, 1995). Of these micronutrients, foliar concentrations of only zinc were significantly reduced by applying greater than $0 \mathrm{mg} \cdot \mathrm{L}^{-1} \mathrm{P}$ concentrations in Hoagland solutions (Table 2). Because foliar concentrations of all macro- and micronutrients except $\mathrm{P}$ were at or near recommended ranges, it is unlikely that treatment differences in con-

centrations of any of those nutrients caused the observed morphological effects. The counterion in this experiment was chloride, because $\mathrm{NH}_{4}$ was added as ammonium chloride. Applied chloride concentrations were inversely proportional to $\mathrm{P}$ treatments. However, based on foliar $\mathrm{P}$ concentrations and observed deficiency $\left(0 \mathrm{mg} \cdot \mathrm{L}^{-1}\right)$ and toxicity $\left(80 \mathrm{mg} \cdot \mathrm{L}^{-1}\right)$ symptoms, is more likely that $\mathrm{P}$, not chloride, caused the observed treatment effects. Thus, either high or low P concentrations in Hoagland solutions were likely responsible for morphological changes in fan flower.

Phosphorus concentrations were always significantly higher when fan flower received any supplemental $\mathrm{P}$ compared with controls, which received no $\mathrm{P}$ after transplant (Table 1). Interestingly, even the lowest solution concentration of $\mathrm{P}\left(20 \mathrm{mg} \cdot \mathrm{L}^{-1}\right)$ resulted in foliar $\mathrm{P}$ concentrations that were over 20 times more concentrated than controls. In the nontreated controls, foliar P concentrations were $0.064 \mathrm{mg} \cdot \mathrm{g}^{-1}$ at $21 \mathrm{DAT}$ (Table 1 ). Foliar P concentrations were even lower at 42 DAT (0.036 mg. ${ }^{-1}$; Table 1). Mills and Jones (1996) report that 0.2 to $0.5 \mathrm{mg} \cdot \mathrm{g}^{-1}$ foliar P may be sufficient for most plants. According to Marschner (1995), foliar P concentrations greater than $1 \mathrm{mg} \cdot \mathrm{g}^{-1}$ may result in $\mathrm{P}$ toxicity. In this experiment, only the nontreated control had foliar P concentrations below $1 \mathrm{mg} \cdot \mathrm{g}^{-1}$, and $\mathrm{P}$ concentrations in those plants were deficient. Phosphorus toxicity symptoms include reduced stem elongation and foliar necrosis and chlorosis (Marschner, 1995). In our experiment, stem length decreased at $\mathrm{P}$ concentrations in

Table 1. Foliar macronutrient concentrations [21 and $42 \mathrm{~d}$ after transplant (DAT)] of fan flower plants grown in Hoagland solutions containing 0 to $80 \mathrm{mg} \cdot \mathrm{L}^{-1} \mathrm{P} .{ }^{\mathrm{z}}$

\begin{tabular}{|c|c|c|c|c|c|c|c|c|c|c|}
\hline \multirow{4}{*}{$\begin{array}{l}\text { Phosphorus in } \\
\text { hydroponics } \\
\left(\mathrm{mg} \cdot \mathrm{L}^{-1}\right)\end{array}$} & \multicolumn{2}{|c|}{ Nitrogen } & \multicolumn{2}{|c|}{ Phosphorus } & \multicolumn{2}{|c|}{ Potassium } & \multicolumn{2}{|c|}{ Magnesium } & \multicolumn{2}{|c|}{ Calcium } \\
\hline & 21 & 42 & 21 & 42 & 21 & 42 & 21 & 42 & 21 & 42 \\
\hline & DAT & DAT & DAT & DAT & DAT & DAT & DAT & DAT & DAT & DAT \\
\hline & \multicolumn{2}{|c|}{$\left(\mathrm{mg} \cdot \mathrm{g}^{-1}\right)$} & \multicolumn{2}{|c|}{$\left(\mathrm{mg} \cdot \mathrm{g}^{-1}\right)$} & \multicolumn{2}{|c|}{$\left(\mathrm{mg} \cdot \mathrm{g}^{-1}\right)$} & \multicolumn{2}{|c|}{$\left(\mathrm{mg} \cdot \mathrm{g}^{-1}\right)$} & \multicolumn{2}{|c|}{$\left(\mathrm{mg} \cdot \mathrm{g}^{-1}\right)$} \\
\hline 0 & $35 b^{y}$ & $25 \mathrm{c}$ & $0.6 \mathrm{~b}$ & $0.4 \mathrm{~d}$ & $59 a$ & $61 \mathrm{a}$ & 4.8 & $3.9 \mathrm{~b}$ & $18 \mathrm{~b}$ & $16 \mathrm{c}$ \\
\hline 20 & $45 \mathrm{a}$ & $50 \mathrm{a}$ & $13 \mathrm{a}$ & $11 \mathrm{c}$ & $59 \mathrm{a}$ & $63 \mathrm{a}$ & 5.0 & $5.8 \mathrm{a}$ & $19 \mathrm{ab}$ & $22 \mathrm{a}$ \\
\hline 40 & $46 \mathrm{a}$ & $44 \mathrm{a}$ & $16 \mathrm{a}$ & $16 \mathrm{ab}$ & $55 \mathrm{a}$ & $61 \mathrm{a}$ & 4.9 & $5.1 \mathrm{a}$ & $19 \mathrm{ab}$ & $19 \mathrm{~b}$ \\
\hline 60 & $43 \mathrm{a}$ & $43 \mathrm{a}$ & $17 \mathrm{a}$ & $20 \mathrm{a}$ & $54 \mathrm{a}$ & $61 \mathrm{a}$ & 5.2 & $5.1 \mathrm{a}$ & $21 \mathrm{a}$ & $19 \mathrm{~b}$ \\
\hline 80 & $37 \mathrm{~b}$ & $35 \mathrm{~b}$ & $11 \mathrm{a}$ & $15 \mathrm{bc}$ & $39 \mathrm{~b}$ & $41 \mathrm{~b}$ & 4.8 & $5.4 \mathrm{a}$ & $17 \mathrm{~b}$ & $19 \mathrm{~b}$ \\
\hline$P$ & 0.0025 & 0.0003 & 0.0016 & 0.0001 & 0.0139 & 0.0019 & NS & 0.0030 & 0.0446 & 0.0007 \\
\hline
\end{tabular}

${ }^{\mathrm{z}}$ Data represent means of three replications for each treatment. $P$ values indicate significant or nonsignificant (NS) trends.

yiffering letters adjacent to means indicate that they are significantly different according to least significant difference means separation.

Table 2. Foliar micronutrient concentrations [ $42 \mathrm{~d}$ after transplanting (DAT)] of fan flower plants grown in Hoagland solutions containing 0 to $80 \mathrm{mg} \cdot \mathrm{L}^{-1} \mathrm{P} .{ }^{\mathrm{z}}$

\begin{tabular}{lccccc}
\hline $\begin{array}{l}\text { Phosphorus } \\
\text { in hydroponics } \\
\left(\mathrm{mg} \cdot \mathrm{L}^{-1}\right)\end{array}$ & $\begin{array}{c}\text { Manganese } \\
\left(\mathrm{mg} \cdot \mathrm{kg}^{-1}\right)\end{array}$ & $\begin{array}{c}\text { Boron } \\
\left(\mathrm{mg} \cdot \mathrm{kg}^{-1}\right)\end{array}$ & $\begin{array}{c}\text { Zinc } \\
\left(\mathrm{mg} \cdot \mathrm{kg}^{-1}\right)\end{array}$ & $\begin{array}{c}\text { Copper } \\
\left(\mathrm{mg}^{-1} \mathrm{~kg}^{-1}\right)\end{array}$ & $\begin{array}{c}\text { Iron } \\
\left(\mathrm{mg}^{-1} \mathrm{~kg}^{-1}\right)\end{array}$ \\
\hline 0 & $\begin{array}{c}113.7 \mathrm{a}^{\mathrm{y}} \\
76.0 \mathrm{bc}\end{array}$ & $38.5 \mathrm{a}$ & $4.27 \mathrm{a}$ & $96.5 \mathrm{a}$ \\
40 & $65.2 \mathrm{ab}$ & $13.4 \mathrm{c}$ & $3.6 \mathrm{a}$ & $85.4 \mathrm{a}$ \\
60 & $69.1 \mathrm{c}$ & $57.8 \mathrm{c}$ & $12.7 \mathrm{c}$ & $3.9 \mathrm{a}$ & $74.7 \mathrm{a}$ \\
80 & $75.2 \mathrm{bc}$ & $61.8 \mathrm{bc}$ & $17.7 \mathrm{c}$ & $4.3 \mathrm{a}$ & $72.0 \mathrm{a}$ \\
$P$ & $89.5 \mathrm{~b}$ & $70.4 \mathrm{ab}$ & $28.0 \mathrm{~b}$ & $2.8 \mathrm{a}$ & $82.4 \mathrm{a}$ \\
\hline
\end{tabular}

${ }^{\mathrm{z}}$ Concentrations of boron, manganese, and zinc were measured, but are not shown. Data represent means of three replications for each treatment. $P$ values indicate significant or nonsignificant (NS) trends.

${ }^{y}$ Differing letters adjacent to means indicate that they are significantly different according to least significant difference means separation. 
Hoagland solutions above $60 \mathrm{mg} \cdot \mathrm{L}^{-1}$. The most severe symptoms of $\mathrm{P}$ toxicity were observed in the highest level of applied $\mathrm{P}\left(80 \mathrm{mg} \cdot \mathrm{L}^{-1}\right)$, but plants fertilized with $60 \mathrm{mg} \cdot \mathrm{L}^{-1} \mathrm{P}$ had some chlorotic leaves. Fan flower fertilized with 40 or $60 \mathrm{mg} \cdot \mathrm{L}^{-1} \mathrm{P}$ had less shoot and root dry weight and leaf area than plants receiving 20 $\mathrm{mg} \cdot \mathrm{L}^{-1} \mathrm{P}$, but did not show extreme toxicity symptoms evident when fan flower were grown at $80 \mathrm{mg} \cdot \mathrm{L}^{-1} \mathrm{P}$. However, based on foliar $\mathrm{P}$ concentrations and observed effects of $\mathrm{P}$ on fan flower morphology, we do not recommend using more than $20 \mathrm{mg} \cdot \mathrm{L}^{-1} \mathrm{P}$. Because the foliar $\mathrm{P}$ concentration of plants grown in even $20 \mathrm{mg} \cdot \mathrm{L}^{-1} \mathrm{P}$ was above levels considered toxic, it is possible that the optimum $\mathrm{P}$ concentration is between the range of 0 to $20 \mathrm{mg} \cdot \mathrm{L}^{-1}$, not 20 to $80 \mathrm{mg} \cdot \mathrm{L}^{-1}$. The foliar concentration of $\mathrm{P}$ preplant was unknown, and we cannot rule out the possibility that high preplant $\mathrm{P}$ applications could have impacted the rate response. Further research should determine the true optimum $\mathrm{P}$ concentrations to apply to fan flower in container media.

High concentrations of $\mathrm{P}$ in foliage are unusual considering that in natural soils, many researchers consider $P$ to be "the most limiting element for plant growth and development" (Vance et al., 2003). However, similar responses have been reported in the literature. Other species native to western Australia, where soils are phosphorus-poor, exhibit phosphorus toxicity at low applied phosphorus concentrations. Banksia ericifolia L. f. (heath-leaf banksia) plants grown in a sedge peat, sand, and perlite $(1: 1: 1 \mathrm{v} / \mathrm{v} / \mathrm{v})$ substrate developed $\mathrm{P}$ toxicity symptoms when they were fertilized with $200 \mathrm{mg} \cdot \mathrm{L}^{-1}$ P (Parks et al., 2000). Shane et al. (2004) report that Hakea prostrata $\mathrm{R}$. Br. (harsh hakea), another western Australian species in the Proteacea family, is less able to reduce P uptake than typical agricultural crop species when P supplies exceed demand. Other species such as wheat have this capacity and do not exhibit toxicity symptoms when $\mathrm{P}$ con- centrations in hydroponic solutions are up to $31 \mathrm{mg} \cdot \mathrm{L}^{-1} \mathrm{P}$ (foliar concentration $=0.87$ $\left.\mathrm{mg} \cdot \mathrm{g}^{-1}\right)$. Hakea prostrata, however, is much more sensitive to phosphorus and develops phosphorus toxicity at external phosphorus supplies as low as $1.6 \mathrm{mg} \cdot \mathrm{L}^{-1} \mathrm{P}$. The concentration of phosphorus in mature leaves is $1.4 \mathrm{mg} \cdot \mathrm{g}^{-1}$ when this plant is grown in hydroponic culture with $3 \mathrm{mg} \cdot \mathrm{L}^{-1} \mathrm{P}$ (Shane et al., 2004).

\section{Conclusions}

Fan flower plants grown hydroponically in 0 to $80 \mathrm{mg} \cdot \mathrm{L}^{-1} \mathrm{P}$ displayed reduced shoot growth and flower development when fertilized with either no $\mathrm{P}$ or $80 \mathrm{mg} \cdot \mathrm{L}^{-1} \mathrm{P}$. Plants fertilized with $\mathrm{P}$ concentrations above 20 $\mathrm{mg} \cdot \mathrm{L}^{-1}$ exhibited some symptoms of phosphorus toxicity. With the highest concentration, phosphorus toxicity was pronounced and plants had chlorotic foliage and poor shoot and root growth. Plants grown in 40 to $60 \mathrm{mg} \cdot \mathrm{L}^{-1} \mathrm{P}$ had minimal to no chlorosis, but did exhibit reduced shoot and root growth. For these reasons, and because foliar $\mathrm{P}$ concentrations exceeded $1 \mathrm{mg} \cdot \mathrm{g}^{-1}$ in plants fertilized with 40 to $80 \mathrm{mg} \cdot \mathrm{L}^{-1} \mathrm{P}$, fan flower should not be fertilized with more than $20 \mathrm{mg} \cdot \mathrm{L}^{-1} \mathrm{P}$. Because the foliar P concentration of even the lowest $\mathrm{P}$ fertilization rate was greater than $1 \mathrm{mg} \cdot \mathrm{g}^{-1}$, the true "optimum" $\mathrm{P}$ fertilization level is likely less than $20 \mathrm{mg} \cdot \mathrm{L}^{-1} \mathrm{P}$.

\section{Literature Cited}

Armitage, A. 1997. Scaevola: A well-traveled plant. Greenhouse Grower 15:61-62.

Armitage, A. 2001. Armitage's manual of annuals, biennials, and half-hardy perennials. Timber Press, Inc., Portland, OR.

Borch, K., T.J. Bouma, J.P. Lynch, and K.M. Brown. 1999. Ethylene: A regulator of root architectural responses to soil phosphorus availability. Plant Cell Environ. 22:425-431.
Freedan, A.L., I.M. Rao, and N. Terry. 1989. Influence of phosphorus nutrition on growth and carbon partitioning in Glycine max. Plant Physiol. 89:225-230.

Hoagland, D.R. and D.I. Arnon. 1950. The waterculture method for growing plants without soil. Calif. Agr. Expt. Sta. Circ. 347 (revised 1950).

James, E. and M. van Iersel. 2001. Ebb and flow production of petunias and begonias as affected by fertilizers with different phosphorus content. HortScience 36:282-285.

Lea-Cox, J.D. and D.S. Ross. 2001. A review of the federal clean water act and the Maryland water quality improvement act: The rationale for developing a water and nutrient management planning process for container nursery and greenhouse operations. J. Environ. Hort. 19: 226-229.

López-Bucio, J., E. Hernández-Abreu, L. SánchezCalderón, M.F. Nieto-Jacobo, J. Simpson, and L. Herrera-Estrella. 2002. Phosphate availability alters architecture and causes changes in hormone sensitivity in the arabidopsis root system. Plant Physiol. 129:244-256.

Marschner, H. 1995. Mineral nutrition of higher plants. 2nd Ed. Academic Press, London, UK.

Mills, H.A. and J.B. Jones, Jr. 1996. Plant analysis handbook II: A practical sampling, preparation, analysis, and interpretation guide. MicroMacro Publishing, Athens, GA.

Parks, S.E., A.M. Haigh, and G.C. Cresswell. 2000. Stem tissue phosphorus as an index of the phosphorus status of Banksia ericifolia L. f. Plant Soil 227:59-65.

Shane, M.W., C. Szota, and H. Lambers. 2004. A root trait accounting for extreme phosphorus sensitivity of Hakea prostrata (Proteaceae). Plant Cell Environ. 27:991-1004.

Vance, C.P., C. Uhde-Stone, and D.L. Allan. 2003. Phosphorus acquisition and use: Critical adaptations by plants for securing a nonrenewable resource. New Phytol. 157:423-447.

Warren, R.G. and B. Benzian. 1959. High levels of phosphorus and die-back in yellow lupins. Nature 184:1588.

Zhang, D., R.E. Moran, and L.B. Stack. 2004. Effect of phosphorus fertilization on growth and flowering of Scaevola aemula $\mathrm{R}$. Br. 'New Wonder'. HortScience 39:1728-1731. 